\title{
THE BASALTS OF SVARTENHUK PENINSULA, PROGRESS REPORT
}

\author{
D. B. Clarke
}

The collection of Tertiary basalt specimens from Svartenhuk Peninsula was undertaken by Pulvertaft and Clarke (1966). The twofold objective was to map the peninsula for the 1:500000 map series and to obtain material for direct comparison with the early Tertiary basalts of south-east Baffin Island, Canada.

Samples were selected for chemical analysis to give the widest possible geographical coverage of fresh material. Of the 40 rocks chosen for analysis 17 were one-phenocryst basalts (olivine only), 12 were two-phenocryst basalts (either olivine + plagioclase or olivine + clinopyroxene) and 11 were three-phenocryst basalts (olivine + plagioclase + clinopyroxene). In general, the number of phenocryst phases increases from $\mathrm{NE}$ to $\mathrm{SW}$ across the peninsula and according to field evidence this is the direction in which the lavas become younger. Petrographic work has revealed that specimens believed to be aphyric in the field contain not less than $5 \%$ microphenocrysts. The significance of this fact is that no lava was erupted above its liquidus temperature. The progressive increase in the number of phenocryst phases with time possibly reflects a lowering of temperature in the magma source, whereas the decreasing size and abundance of olivine with time reflects crystal-liquid fractionation in the source.

At the time of writing, the analyses are not yet complete but several interesting facts have already emerged. In addition to the usual major elements, the following trace elements have been determined by $X$-ray fluorescence:

$\mathrm{Ba}, \mathrm{Cr}, \mathrm{Cu}, \mathrm{Ga}, \mathrm{Ni}, \mathrm{Rb}, \mathrm{Sr}, \mathrm{Y}, \mathrm{Zn}, \mathrm{Zr}$. $\mathrm{Ni}$ and $\mathrm{Cr}$ are known to be preferentially removed from the liquid by olivine and picotite respectively, and it is precisely the early picritic basalts which are enriched in these two elements. The other 
trace elements tend to be concentrated in the liquid phase to varying degrees during fractional crystallization of the magma. Simple variation diagrams of one element against another have been plotted for various pairs of geochemically related elements. The analyses plotted in this manner demonstrate, in most cases, a strong linear evolution of the magma from a primitive condition in the $\mathrm{NE}$ to a more highly evolved state on the SW of the peninsula. Therefore, the chemical data is in complete agreement with field and petrographic evidence.

On the Canadian side of Baffin Bay the most remarkable feature of the Baffin Island basalts is their exceptionally low potash content which ranges from $0.02-0.17 \% \mathrm{~K}_{2} \mathrm{O}$. Deep ocean tholeiites exhibit similar low levels of potash but continental occurrences are exceedingly rare. It is therefore of considerable significance to discover that 25 of the analyzed Svartenhuk basalts have $\mathrm{K}_{2} \mathrm{O}<0.20 \%$ and the complete range is $0.06-0.85 \% \mathrm{~K}_{2} \mathrm{O}$. Again the highest values are recorded in the youngest rocks. The relationship between the potash levels of Baffin Island and West Greenland (i. e. that the Baffin Island suite lies at the more basic or primitive end but overlaps the variation in the West Greenland suite) is repeated on every variation diagram involving pairs of other elements. And, just as important, the two suites lie on the same straight lines on the variation diagrams.

The tentative petrogenetic implications are that:

1 ) if the level of $\mathrm{K}_{2} \mathrm{O}$ is a reliable criterion of the stage of evolution of a magma, then these rocks represent very primitive mantle derivatives;

2) the continuous linear trends represent successive differentiation products of one slowly evolving source;

3) the eruptions on Baffin Island began before those on West Greenland and the geochemical overlap suggests an overlap in the time of volcanic activity.

The present geographical relationship of the two areas would preclude such a close geochemical relationship between their lavas. 
It therefore becomes increasingly attractive to conclude that the two areas have been separated by continental drift either after, or probably during, the phase of volcanic activity.

Reference

Pulvertaft, T.C.R. and Clarke, D.B. (1966) New mapping on Svartenhuk Peninsula. Rapp. Grønlands geol. Unders., Nr. 11, $15-17$.

\section{ANGIOSPERMOUS LEAVES FROM THE LOWER CRETACEOUS KOME FORMATION OF NORTHERN WEST GREENLAND}

\section{K. Raunsgaard Pedersen}

The Kome Formation occurs on the north side of Nugssuaq peninsula $\left(70^{\circ} 5^{\prime} \mathrm{N}\right)$ in northern West Greenland. It extends from Ikorfat $\left(53^{\circ} 5^{\prime} \mathrm{W}\right)$ eastwards to Kâk.

The limnic sediments of the Kome Formation, comprising shales, coal seams and sandstones, lie on weathered Precambrian gneisses and are overlain by a younger limnic formation with more sandy sediments. The two formations are separated by a low-angle unconformity'at a height of $400-500 \mathrm{~m}$. The upper limnic formation has been shown by means of plant microfossils to belong to the lower part of the Upper Cretaceous. In the western part of the area the two limnic formations are overlain by marine sediments of Senonian age (Rosenkrantz, 1951).

Judging from micro- and macroscopic plant remains the Kome Formation is of Lower Cretaceous age (Barremian-Aptian). This is the age originally suggested by Heer (1883, p.157), but for a long time afterwards the age was thought to be Upper Cretaceous because 